three hours. If this mixed sample does not give any stronger reaction than previous samples it can be assumed fairly safely that the reducing agent is not glucose. If, however, the test becomes obviously more strongly positive after the meal, the condition is almost certainly glycosuria and a full glucosetolerance test must be carried out if the occasional case of diabetes mellitus is to be excluded.

\section{Vasomotor Rhinitis}

Q.-What forms of therapy will relieve the discomfort of nasal obstruction arising from a swelling of the soft tissues lining the nasal airways? The obstruction takes place indoors, and especially when in bed at night. Change of posture and exercise, particularly in the open air, give a free airway temporarily. Ephedrine spray and the other decongestants give transient relief, if not repeated too often. There is no evidence now of an infection which was successfully treated 10 years ago by a bilateral intranasal antrostomy. The air passages have otherwise been declared free from any mechanical obstruction.

A.-The probable diagnosis is vasomotor rhinitis, which may respond to so-called "diastolization." This is essentially a method of massaging the spongy tissues covering the turbinates by means of soft rubber hollow bougies connected to a Politzer bag. Should this prove insufficient, linear cautery of the inferior turbinates should be tried. If all minor treatment fails, removal of part of the middle, or of the enlarged posterior ends of the inferior, turbinates is indicated.

\section{Ascorbic Acid Oxidase}

Q.-In an annotation, "Vitamin $C$ and Benzene Poisoning," in the Journal of December 31, 1949, there is a reference to the work of Ekman, who found that greater protection was given to guinea-pigs exposed to benzene vapour when ascorbic acid and ascorbic acid oxidase were given than when ascorbic acid alone was used. At the present season it is difficult to obtain cucumbers, which contain large amounts of ascorbic acid oxidase. What other sources of ascorbic acid oxidase are available at this time of the year and suitable for consumption?

A.-Ekman stated that he got better results with ascorbic acid and a source of ascorbic acid oxidase or with citrin. Cucumber is one of the best sources of ascorbic acid oxidase, but other sources are fresh uncooked fruit and vegetables. The ascorbic acid oxidase is formed when these are macerated or shredded and is destroyed on boiling.

\section{Loewi's Mydriatic Test}

Q.-What is the mechanism of Loewi's mydriatic test in cases of acute pancreatitis, and is this test of any value in cases of subacute or chronic pancreatitis?

A.-The explanations advanced for Loewi's mydriatic test are more ingenious than credible. The two most frequently cited are that irritation of the coeliac ganglion by the inflamed pancreas renders the sympathetic nervous system unduly sensitive to adrenaline. and that hypo-insulinism, by evoking hyperadrenalism, has the same effect.

The test has to be regarded as non-specific; negative results occur in some cases of acute pancreatitis and positive in some other diseases, notably thyrotoxicosis. It is probably true to say that most clinicians have discarded the test as worthless.

\section{Anal Fissure}

Q.-What is the best treatment for anal fissure? A patient in his eightieth year and in fair health suffers daily agony during and after defaecation. Is there a cure and, if so. is it permanent?

A. - The treatment of anal fissure may be palliative, or by injection, or surgical. Palliative treatment (the avoidance of constipation, careful anal hygiene at stool, and the subsequen use of an analgesic ointment) is likely to be effective only in early cases. The infiltration of the tissues immediately subjacent to the fissures and of the corresponding part of the external sphincter muscle with $10-15 \mathrm{ml}$. of "proctocaine" is very often most successful. If this should fail, excision of the entire fissure and section of the underlying external sphincter muscle will give certain relief at the price of a rather lengthy healing period (the discomforts of which can be considerably reduced by hot baths and by infra-red light). In the case under consideration any prolonged period in bed is probably better avoided, and hence injection (at least once) would seem strongly indicated.

\section{Prognosis in Hemiplegia}

Q.-What is the prognosis in hemiplegia where there is no other disturbance of cerebral function? When should walking exercises be begun and how long does it usually take to establish complete or partial recovery? What sort of treatment is called for in these cases in elderly people?

A. - In cases of acquired hemiplegia of vascular origin, the prognosis naturally depends upon the severity of the lesion, which cannot always be estimated at the time of onset. Sometimes recovery is almost complete. In such cases there is usually fairly rapid improvement in the course of the first two or three weeks. In more severe cases recovery in the upper limbs is always incomplete, for the patient is likely to have little power in the hand, but walking almost always becomes possible. The patient can usually be allowed to make some attempt at standing three weeks after the stroke, and should be able to walk a little in another three or four weeks; the maximum improvement is likely to be reached in three to six months. Some details of the management of patients following cerebral haemorrhage were given, in reply to another question, in the issue of March 18 at p. 681 .

\section{NOTES AND COMMENTS}

Adrenaline Cream.-Mr. P. G. SHuTE (Epsom, Surrey) writes : As the reply given under this heading in "Any Questions?" (March 18 , p. 681) suggests that adrenaline cream is of little or no value, I would like to state that in my case I am confident that it has been highly beneficial. In 1943 I suffered a severe attack of sciatica, and for the past six years I have been a victim of almost continuous pain in the region of the ribs and shoulders from what has been diagnosed as fibrositis. Daily massage combined with radiant heat for months on end gave me only temporary relief. I also had numerous Turkish baths combined with massage over a period of two years, and these too gave me freedom from pain for at the most a few hours. Three months ago I tried adrenaline cream $(1-5,000)$, and in my experience it has been well worth while. The dull aching pain around my ribs has cleared up, and although I still get pain on the points of the shoulders adrenaline cream brings relief within the hour of its application, even if it is merely smeared on without deep massage.

Survival of the Flea.-Dr. AdaIr Girby (Edinburgh) writes: With reference to Mr. G. C. Adeney's remarks (February 18, p. 448) on the sudden appearance of large numbers of fleas in a semi-ruined building, the explanation is more or less as follows. Fleas will lay their eggs, sometimes in enormous numbers, in empty buildings or occupied premises which are subsequently evacuated. The matting on the floor, so common in Eastern countries, constitutes an ideal nidus for the eggs, which in the absence of any stimuli remain in a quiescent state for months or even years. As soon as the building is entered, however, the vibration of footsteps will activate the insects, which are apparently ready to emerge instantly if given the opportunity. Accordingly they hatch out by the score and make for the cause of the disturbance, be it human or animal. In the course of a few minutes it is possible to be almost completely. covered with a carpet of writhing, newborn fleas, busily disporting themselves after their long entombment. Visitors entering in whịte drill suits are observed to emerge hurriedly, apparently clad in black from head to foot. It is altogether a most a!arming experience.

Correction.-Dr. Hugh McLaren (Birmingham) writes: In my article on "Cancer of the Uterus in Adrenogenitalism" (April 1, p. 763) there is an error. The reference to "serum potassium, $320 \mathrm{mg}$. per $100 \mathrm{ml}$." should have read "serum sodium, $300 \mathrm{mg}$. per $100 \mathrm{ml}$; serum potassium $20 \mathrm{mg}$. per $100 \mathrm{ml}$."

All communications with regard to editorial business should be addressed to $T H$ EDITOR, BRITISH MEDICAL JOURNAL B.M.A HOUSE, TAVISTOCK SOUARE, EUSTON 2111. TELEGRAMS: Aitiology, Westcent, London. ORIGINAL ARTICLES AND LETTERS forwarded for publication are understood to be offered to the British Medical Journal alone. Authors desiring REPRINTS should communicate with the Publishing Manager. B.M.A. House, Tavistock Square, W.C.1, on receipt of proofs. ADVERTISEMENTS should be addressed to the Advertisement Marager B.M.A. House, Tavistock Square. London, W.C.1 (hours 9 a.m. to 5 p.m.) TELEPHONE: EUSTON 2111. TELEGRAMS: Britmedads, Westcent London. MEMBERS' SUBSCRIPTIONS should be sent to the SECRETARY of the Association. TelePhONE: EUSTON 2111. TElegrams : Medisecra, Westcent. London.

B.M.A. Scottish OfFice: 7, Drumsheugh Gardens, Edinburgh. 